Vol 2, No 1 (2019): Stadium - Hungarian Journal of Sport Sciences

https://doi.org/10.36439/SHJS/2019/1/2928

\title{
QUALITY OF WELLNESS SERVICES IN THE NORTH GREAT PLAIN REGION
}

\author{
Hidvégi Péter1, Bíró Melinda1, Lenténé Puskás Andrea1, Tatár András ${ }^{1}$ \\ Bárdos Kinga ${ }^{2}$, Pucsok József Márton ${ }^{1}$ \\ ${ }^{1}$ University of Debrecen, Institute of Sport Sciences, Debrecen \\ 22Dobó István High School, Eger
}

\begin{abstract}
Wellness is the philosophy of life in everyday life. In a holistic sense, it is also used as a harmony of physical, mental, and spiritual abilities, basically means prevention, regeneration, relaxation, and fitness. The investigation took place between September and December 2018. Of the 166 participants, 94 were women, and 72 were men. As a result of the research, we can state that respondents are looking for relaxation and relaxation in wellness hotels. Their expectations are related to their age, place of residence, and family status.
\end{abstract}

Keyword: wellness, wellness services, health tourism 
Vol 2, No 1 (2019): Stadium - Hungarian Journal of Sport Sciences

https://doi.org/10.36439/SHJS/2019/1/2928

\section{THEORETICAL BACKGROUND}

\section{DEFINITION OF HEALTH AND WELLNESS}

The future development and the economic potential of a country depend mainly on the health of the population (SIMON-KISS, 2003). The World Health Organization defined it in 1948 as follows: "Health is a state of complete physical, mental and social well-being and not just a lack of disease" (WHO, 1946). In 1986, Seedhouse put health in a more sophisticated approach, "The optimal state of health is equal to the set of conditions that an individual can develop into the full range of options available to him." (SEEDHOUSE, 1986). Insel and Roth provided a broader definition of health as an: emotional, environmental, intellectual, social, spiritual, intellectual, and physical well-being (INSELROTH, 2007).

Wellness is one of the most decisive trends nowadays. Wellness is the physical-spiritual harmony, the essence of which physical appearance is accompanied by inner beauty and balance (TÖRŐCSIK, 2014).

Wellness is only a seemingly new trend; in fact, it has the same age as mankind, with the effort to fight for self-sufficiency, to improve physical and mental fitness, to prevent the development of illnesses. Such aspirations were, for example, the ancient Greek kalokagathia, which sought to establish the unity of the body and soul, but also the holistic approach or the Renaissance Human theory (HOJCSKA-SZABÓ, 2010).

Wellness is a lifestyle; if you prefer a health-conscious lifestyle that improves your physical and mental balance and fitness. The phrase "wellness" was first introduced at the end of the fifties. According to one interpretation, wellness is a combination of words of well-being and wholeness, while others derive it from the combination of well-being and fitness, as the counterpart of illness. (FODOR, SZILAGYI, 2014).

The term itself was born in 1950 by American physician Halbert Dunn, who created wellbeing (well-being) and fitness (functional physical fitness). He believed that people should primarily rely on themselves and, as far as possible, does everything they can to their health; According to Dunn, body, soul, and spirit are inseparable from each other for good health. Dr. Donald Ardell, one of the prominent figures in the wellness movement, is the merit of introducing the concept of wellness to the public (ÁRPÁSI, 2014).

Wellness activities such as (gymnastics, healthy eating, swimming, fitness, massage, etc.) may be integrated into everyday life, but more preferably people attend those activities regularly (4-5 days or one week) as part of treatment in a hotel (HÉZSŐNÉ, 2011; LENTÉNÉ et al., 2018).

Wellness brings philosophy to everyday life. In a holistic sense, it is also used as a harmony of physical, mental, and spiritual abilities, basically means prevention, regeneration, relaxation, and fitness. So, wellness incorporates healthy and conscious, living, may improve or preserve the health of the body and soul.

"If we accept that the name can be interpreted as a controversial pair of diseases in Hungarian translation, that is, health, then wellness first and foremost represents a form 
of life in which the individual strives for an optimal, harmonious state of the body, soul, and spirit" (MICHALKÓ, 2004).

\section{WELLNESS SERVICES}

So, wellness is also a multitude of words that reflects lifestyle. Primarily, wellness services have been created to get a better understanding of ourselves and our world. We can get advice on lifestyle, physical appearance, nutrition, dressing, personality, and the same time, we are encouraged to do sport and exercise regularly. Maintaining a healthy lifestyle is the primary goal, and various wellness services have been created for this reason (PUCSOK et al., 2018a).

Wellness services could be separated into two groups. They may be passive and active. Passive activities are just when we are in a sitting, standing, or lying position for a long time and enjoy the wellness services. Massage is such an activity, for example. Sauna is also included in the wellness services. There are many varieties, like Finnish, infra, and bio sauna exist. The beneficial effect of a sauna is primarily to relax but also have physiological severe, this way recreational effects too. Facial treatments and a variety of cosmetic procedures are also available, which also crucial in wellness services and available in almost all wellness centers'. Activities include aqua fitness, but we interpret this more in-depth later. Sports and exercise facilities such as tennis and squash can also be considered as wellness services. Also, wellness hotels provide bowling, and the majority of rural hotels also offer horseback riding and organized hiking opportunities. Most of these are also classified as wellness services.

Wellness should become a lifestyle developing our way of life to achieve a balanced state of our body, soul, and spirit while respecting our choices and our opportunities. Making such prosperity in today's accelerated lifestyle is a particular challenge all of us. If we look closely, wellness is everywhere around us; we have to realize, we have to practice. Beyond the wellness, as mentioned earlier tourism, may consist of spiritual ascension, healthy eating, morning walks, physical activities, friendships, and positive thinking (PUCSOK et al. 2018b).

\section{THE RESEARCH}

The research took place from September to December 2018. The survey was carried out with a questionnaire survey, and the guests arriving in the North Great Plain region were interviewed by the respondents, which were filled by their own decision. Questionnaire questions included simple choice, multiple choice, open questions, and Likert scales.

Our research questions focused on the parameters that characterize the wellness services of the North Great Plain region. Our study aimed to identify the general statistical characteristics of the participants in the service, to help the wellness providers in the area 
to determine the target group. The target group of the research was the users of wellness services. This article is part of a more extensive study.

The methodology of the research is primarily based on descriptive statistical indicators. For this purpose, cross-table analyzes and distributions were investigated, and Pearson's correlation analysis was performed for correlation analysis. Computer-based data transfer was done with the Gmail Drive questionnaire program; the data was exported and statistically analyzed with SPSS 20 . The tables and graphs were displayed with Office 2013 Excel. In this article, we mainly work with rounded data to present the study.

\section{RESULTS}

First, we examined the characteristics of the participants. The following results were obtained from the 166 respondents. Respondents were $43.4 \%$ male and $56.3 \%$ female.

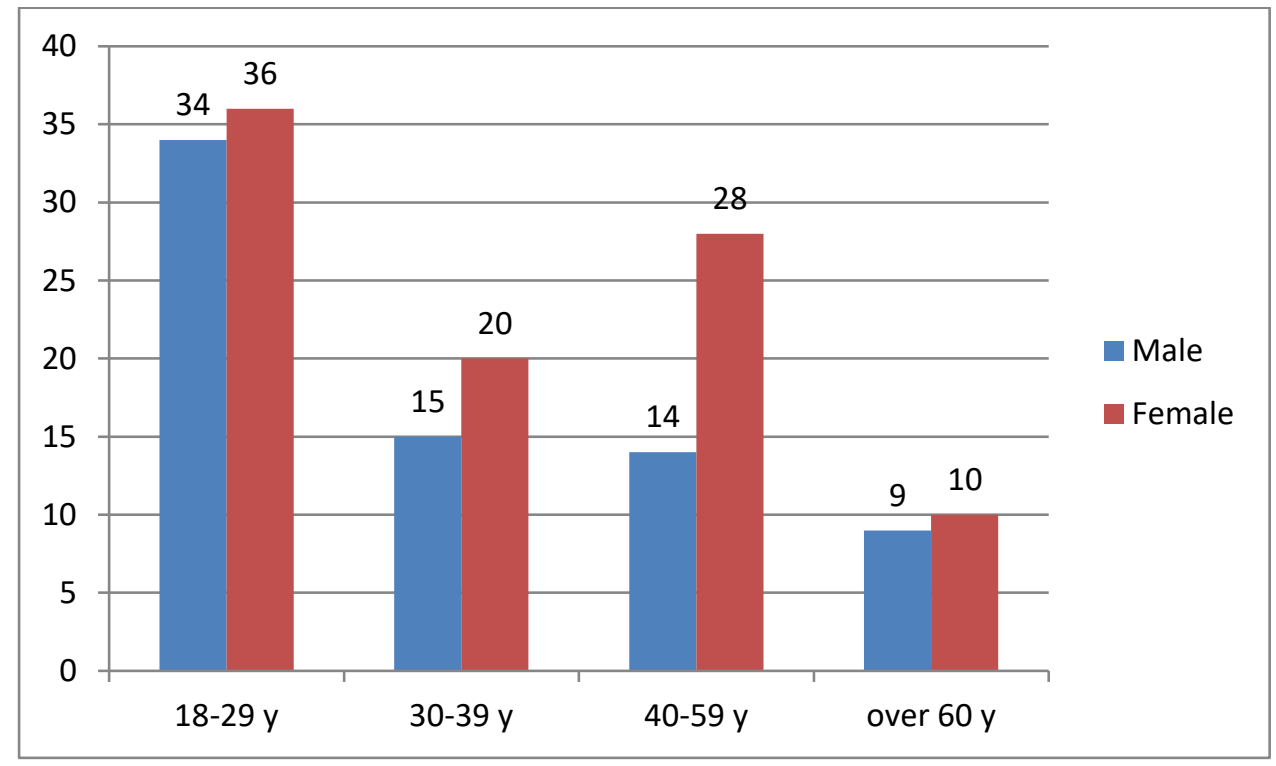

Figure 1: Age categories

In terms of their family status, we distinguished four groups, based on which almost half of the respondents live in some kind of a relationship (Figure 2). In terms of family status, singles are almost equally represented in both males and females. In terms of educational background, only one person has primary education and 55\% with secondary school, followed by $44 \%$ with higher education. Of the spouses, 45 are graduates, and 16 are married, and ten are divorced. In contrast, 43 of those with the secondary school are single, 5-5 is divorced or widowed, and 39 are married. 
Vol 2, No 1 (2019): Stadium - Hungarian Journal of Sport Sciences

https://doi.org/10.36439/SHJS/2019/1/2928

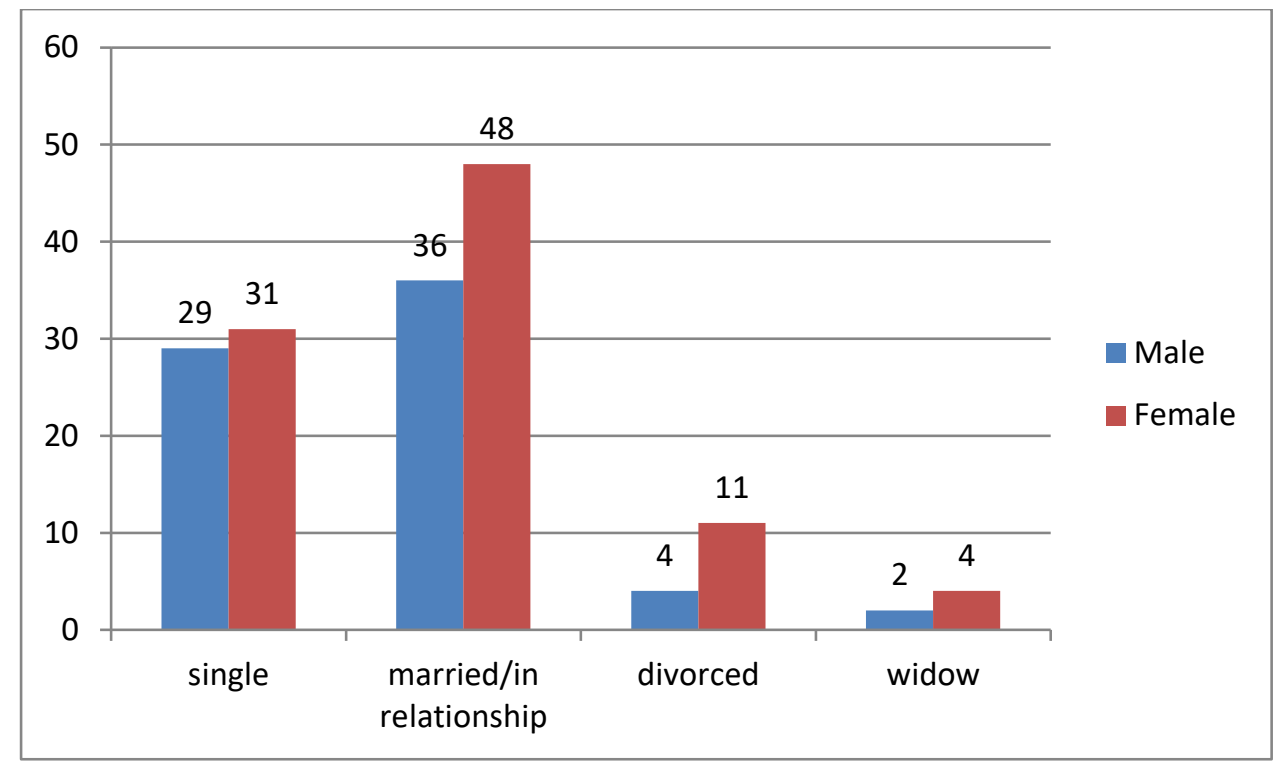

Figure 2: Family status

Our research also focused on the place of residence, and we found that respondents came mainly from the North-eastern region, 14 out of 20 counties - 45\% from Hajdú-Bihar county. According to the type of residence, 77 people answered they live in towns, 51 in smaller cities, 12 in the capital and 26 in some smaller settlements.

Twenty-five of the participants in the wellness service replied they had a family member with a disability. As shown in Figure 3, the majority of the family members with a disability were represented. The least number of people with speech disabilities and the severely disabled family member was also indicated. Two people reported having autistic family members.

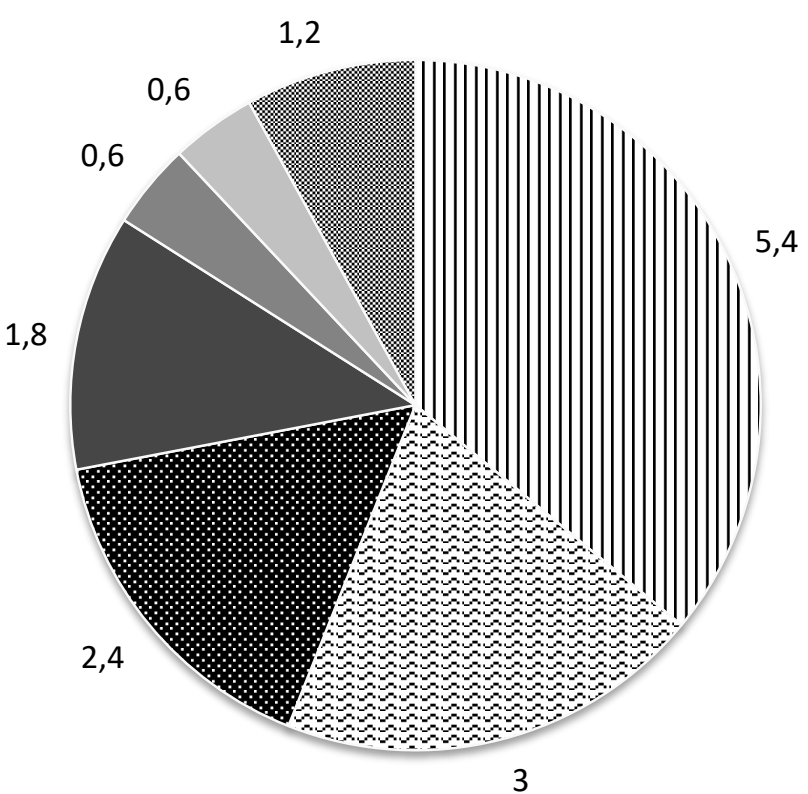

I disabled

visually impaired

hearing impaired

- mental disability

- speech disorder

severly disabled

autistic 
Vol 2, No 1 (2019): Stadium - Hungarian Journal of Sport Sciences

https://doi.org/10.36439/SHJS/2019/1/2928

Figure 3: Disability categories

General beliefs about wellness are complex. Those who filled the multiple-choice questionnaire, $90 \%$ of them indicated having a rest, and relaxation as their priority. Confidence or the light body workout was the least frequent choices. Charging with energy or regeneration choices reached an average value.

Respondents were asked to rate statements on a six-point scale about their wellness habits. As shown in Figure 4, respondents' opinions were quite divided on the issue. The highest values $(5,02$ and 4,43), demonstrated, that respondents found that the sauna and massage, the spa and thermal water are an essential part of the wellness services. There is hardly any difference between the idea that physical and mental health is the goal of wellness.

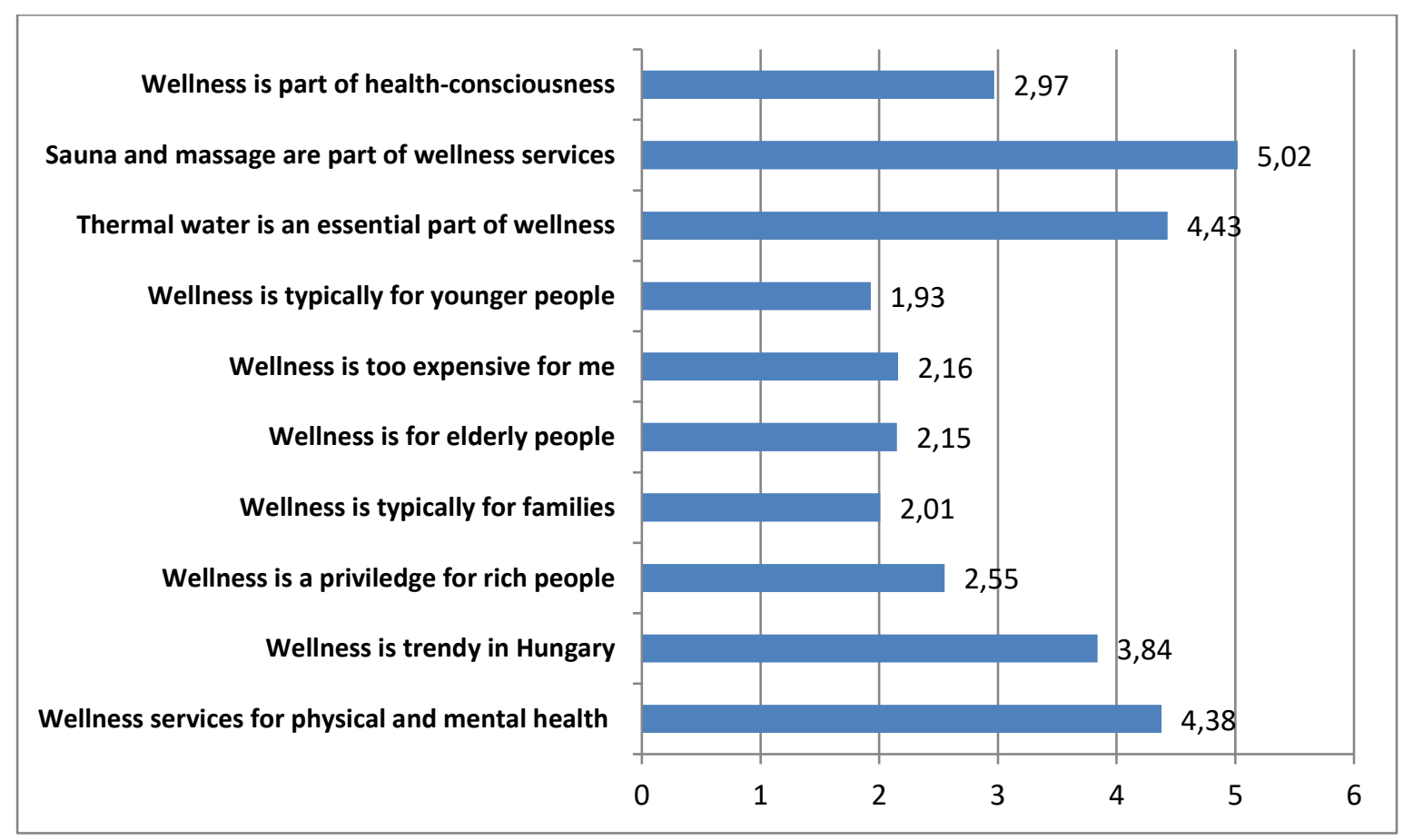

Figure 4: Statements on wellness according to the respondents

As Figure 5 indicated, having a rest is the fist, calm environment is the second most crucial motive when choosing wellness location. Although only $15 \%$ of respondents stated that they had some disability, the third priority was to have accessibility (average value 3.69) followed by the claim to have some childcare. The probable reason for this expectation is that 84 of the 166 respondents live in some relationship, possibly divorced, so they have a child or plan to have some. 
Vol 2, No 1 (2019): Stadium - Hungarian Journal of Sport Sciences

https://doi.org/10.36439/SHJS/2019/1/2928

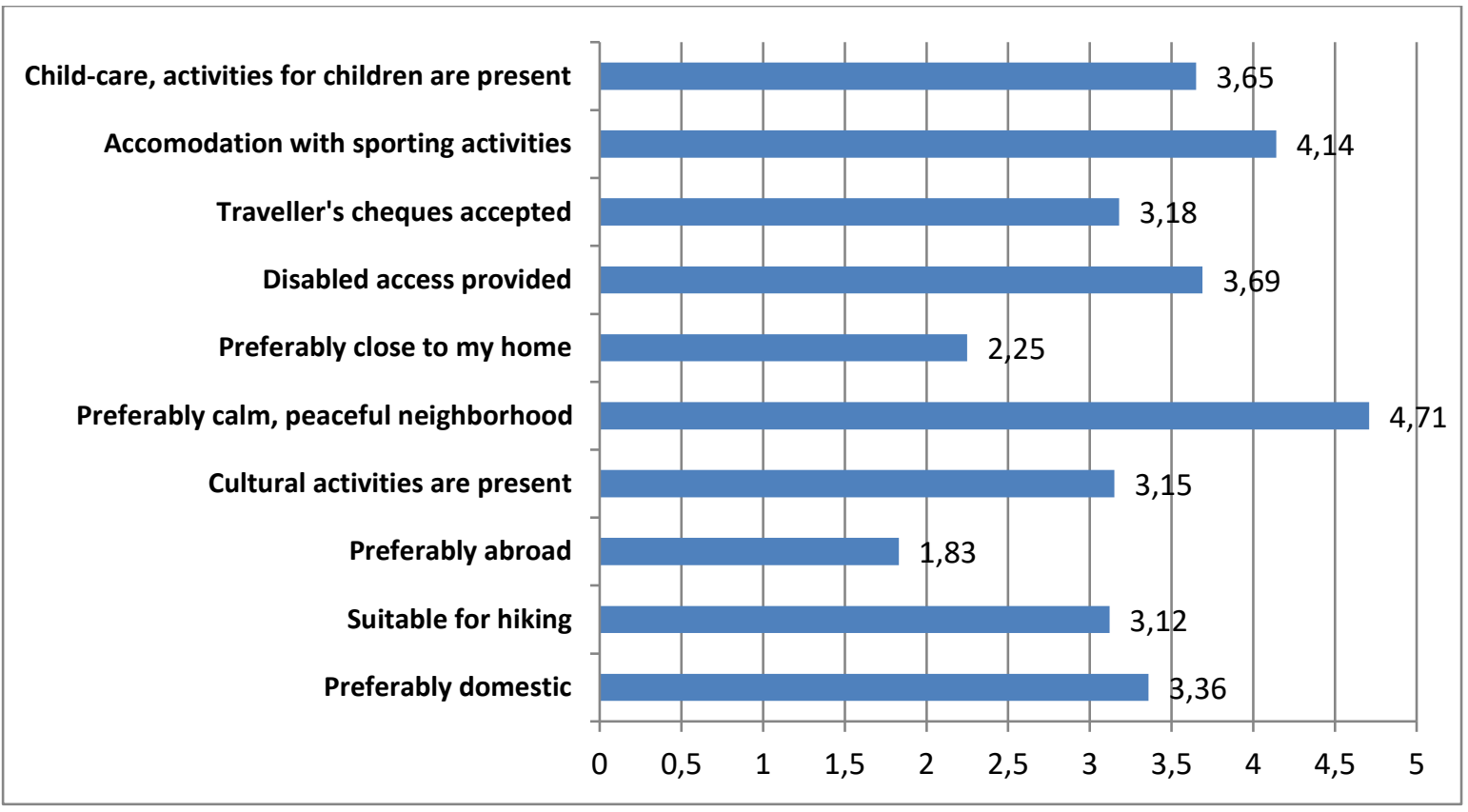

Figure 5: The importance of each factor in choosing a wellness location

To prove our statement, we examined the relationship between respondents and family status, and we got a strong relationship between family status and the importance of the above-listed factors in choosing a wellness location. As shown in Table 1, there is a strong relationship between calm neighbourhood $(r=0.912, p=0.05)$ and sporting activities $(\mathrm{r}=0.886, \mathrm{p}=0.05)$ and family status.

Table 1: The relationship between family status and choice of well-being

\begin{tabular}{|l|c|}
\hline $\begin{array}{l}\text { Correlations between statements on wellness and } \\
\text { family status }\end{array}$ & $\begin{array}{l}\text { Significance level } \\
\mathbf{( p = 0 . 0 5 )}\end{array}$ \\
\hline Preferably domestic & 0.025 \\
\hline Suitable for hiking & 0.317 \\
\hline Preferably abroad & 0.218 \\
\hline Cultural activities are present & 0.369 \\
\hline Preferably a calm and peaceful neighborhood & 0.912 \\
\hline Preferably close to my home & 0.496 \\
\hline Easily accessible & 0.214 \\
\hline Use of traveler's cheques & 0.439 \\
\hline Accommodation with sporting activities & 0.886 \\
\hline Child-care, activities for children are present & 0.618 \\
\hline
\end{tabular}

We were looking for a similar relationship between age and wellness expectations. Based on the ANOVA examination, we also found a correlation between age and expectations, 
Vol 2, No 1 (2019): Stadium - Hungarian Journal of Sport Sciences

https://doi.org/10.36439/SHJS/2019/1/2928

although not as strong as family status. The level of significance, as shown in Table $2(\mathrm{p}=$ $0.05)$, was found between child care ( $\mathrm{r}=0.677)$ and accessibility ( $\mathrm{r}=0.650)$, although these demonstrate a rather moderate relationship.

Table 2: Relationship between age and wellness expectations

\begin{tabular}{|l|c|}
\hline $\begin{array}{l}\text { Correlations between statements on wellness and } \\
\text { age }\end{array}$ & $\begin{array}{l}\text { Significance } \\
\text { (p=0.05) }\end{array}$ \\
\hline Preferably domestic & 0.137 \\
\hline Suitable for hiking & 0.468 \\
\hline Preferably abroad & 0.340 \\
\hline Cultural activities are present & 0.303 \\
\hline Preferably a calm and peaceful neighborhood & 0.414 \\
\hline Preferably close to my home & 0.573 \\
\hline Easily accessible & 0.650 \\
\hline Use of traveler's cheques & 0.303 \\
\hline Accommodation with sporting activities & 0.086 \\
\hline
\end{tabular}

Finally, based on the type of place of residence, we also examined whether we have any relationship with expectations. Although we did not assume a stronger relationship between them, as shown in Table 3, there was a moderately strong relationship between the place of residence and expectations in the case of the peaceful neighborhood $(r=0.664$, $\mathrm{p}=0.05)$ and cultural activities $(\mathrm{r}=0.605, \mathrm{p}=0.05)$.

Table 3: Place of residence

\begin{tabular}{|l|c|}
\hline $\begin{array}{l}\text { Correlations between statements on wellness and place } \\
\text { of residence }\end{array}$ & $\begin{array}{l}\text { Significance level } \\
(\mathbf{p = 0 . 0 5})\end{array}$ \\
\hline Preferably domestic & 0.335 \\
\hline Suitable for hiking & 0.172 \\
\hline Preferably abroad & 0.105 \\
\hline Cultural activities are present & 0.605 \\
\hline Preferably a calm and peaceful neighborhood & 0.664 \\
\hline Preferably close to my home & 0.261 \\
\hline Easily accessible & 0.010 \\
\hline Use of traveler's cheques & 0.315 \\
\hline Accommodation with sporting activities & 0.261 \\
\hline Child-care, activities for children are present & 0.415 \\
\hline
\end{tabular}


Based on this research, we may conclude that most respondents interested in wellness holidays live in a relationship and middle-aged, looking for having a rest in these accommodations, preferring locations with spa, and thermal water options. Their expectations are related to their age, place of residence, and family status. Based on our data, middle-aged, urban residents, from Hajdú-Bihar County are the leading target group for wellness trips. Their most important expectation was the peaceful surroundings, the sports facilities, and for the families with young children child care and accessibility. In their free time, they would like to participate in cultural activities and relax in a calm environment.

This study was supported by the EFOP -3.6.2.-16-2017-00003 Project. The project was funded by the European Union and co-financed by the European Social Fund.

\section{REFERENCES}

Árpási, Z. (2014). Opportunities for developing wellness tourism services in the Southern Great Plain Region. Doctoral Dissertation. Szent István University, Gödöllő.

Fodor, M., Szilágyi, P. (2014). Possibilities of wellness as a health preservation project in the development of regions in the light of primary consumer data.

Hézsőné, BA. (2013). The development of culture, a brief overview of its diversity. In: Győr, F, Hézsőné, B.A. Kiss, G. Lehmann, D.A., Meszlényi-Lenhart, E. Balogh, L. (2013). Wellness, Sports, and Health Tourism.

Hojcska, ÁE., \& Szabó, Z. (2010). Physiotherapy in Health Tourism, Educational Aid.

Insel, P., \& Roth, W. (2007). Core Concepts in Health. Brief Update. McGraw-Hill Humanities, New York.

Lenténé, Puskás A., Hidvégi, P., Tatár, A., Pucsok JM., \& Biró, M. (2018). A rekreációs turizmus lehetőségei Magyarországon az Észak-alföldi régióban, Válogatott tanulmányok a sporttudomány köréből-Fókuszban az egészség, I. kötet.

Michalkó, G. (2004). The Basics of Tourism Theory. János Kodolányi College, Székesfehérvár. 
Pucsok, JM., Hidvégi, P., \& Lenténé, Puskás A. (2018a). A belföldi elsődleges (primer), másodlagos (szekunder) wellness turizmus trendjei Hajdú -Bihar megyében, Válogatott tanulmányok a sporttudomány köréből-Fókuszban az egészség, I. kötet.

Pucsok, JM., Biró, M., Balogh, L., Tatár, A., Hidvégi, P., \& Lenténé, Puskás A. (2018b). The international trends of inner wellness and its feasibility in the North Great Plain region, Hungary -a systematic review. Geosport for Society, 9, (2), 82-87.

Seedhouse, D. (1986). Health: The Foundations for Achievement. John Wiley, Chichester.

Simon-Kiss, G. (2003). Health is more than just giving it to doctors. Health Management, 13 (1): 89-91.

Törőcsik, M. (2014). Consumer behavior of generations, marketing consequences, $D r$. Töröcsik Marketing Inspiration. In: Árpási, Z .: Analysis of the Image of the South Great Plain Region: Development Opportunities in the Regional Market of Wellbeing Services. Hungarian Marketing Association.

World Health Organization. (1946). Constitution, Geneva. 